\title{
Waste Heat Recovery for Fuel Cell Electric Vehicle with Thermochemical Energy Storage
}

\author{
Mounir Nasri, Inga Bürger, Schier Michael, Horst E. Friedrich \\ German Aerospace Center (DLR) \\ Pfaffenwaldring 38-40 \\ 70569 Stuttgart, Germany \\ Email: Mounir.Nasri@dlr.de, Inga.Buerger@dlr.de, \\ Michael.Schier@dlr.de, $\underline{\text { Horst.Friedrich@dlr.de }}$
}

\begin{abstract}
In this paper, different waste heat recovery concepts for a high temperature fuel cell range extender vehicle developed by the DLR Institute of Vehicle Concepts will be presented. These concepts use thermochemical heat storages to recover thermal energy from the powertrain waste heat and to re-use it for heating purpose before or during the drive. The focus will be on metal hydride storages, which have a higher specific energy density than the phase change energy storages and will thus be more advantageous for vehicle application.

In order to investigate the developed waste heat recovery concepts in the entire vehicle, appropriate simulation models will be created in the simulation environment Modelica/Dymola, then integrated into an overall vehicle simulation model. It is found that the integration of the thermochemical heat storages into the fuel cell thermal management system leads to increase the range by up to $17 \%$.
\end{abstract}

Keywords-waste heat recovery; energy storage; fuel cell vehicle; thermochemical system; powertrain; thermal management

\section{INTRODUCTION}

The expected increasing electrification of vehicles leads to a reduced thermal energy potential in the vehicle due to a very high efficiency of the e-powertrain.

Fuel heaters can be used to maintain the range of electric vehicles, but they are not emission-free, and so their use damages the image of electric vehicles. Heat pumps can use ambient heat for heating and relieve the battery, but they have the problem: that their efficiency decreases at ambient temperatures lower than $5^{\circ} \mathrm{C}$, and consequently a lot of electricity and heat is required [1]. The main reason for that is icing of the outdoor heat exchanger and long defrosting periods at low ambient temperatures.

Fuel cell electric vehicles have the advantage over battery electric vehicles because they produce higher waste heat which can be used for heating purpose. When the fuel cell is activated, the generated waste heat is around $40 \%$ of the consumed fuel power and can be used for the cabin and battery heating.

However, at the beginning of vehicle operation, there is not sufficient waste heat for the preheating of the battery, cabin and even the fuel cell itself. This lack of waste heat is usually covered by a positive temperature coefficient (PTC) heater, which converts the electricity from the battery into heat, and consequently the electric range is considerably reduced.

In this paper various waste heat recovery concepts for a fuel cell electric vehicle based on thermochemical heat storage system will be presented, modelled and discussed.

\section{Fuel Cell Vehicle Modelling}

\section{A. The High-Temperature Fuel Cell Vehicle}

The DLR Institute of Vehicle Concepts is developing a fuel cell range extender vehicle [2], which is based on the e-powertrain of the Smart Fortwo vehicle [3] manufactured by Daimler AG and uses a high temperature polymer electrolyte membrane fuel cell (HT-PEFC) as a range extender (REX) unit.

The Smart Fortwo electric vehicle has a lithium-ion battery whose capacity amounts to $17.6 \mathrm{kWh}$ and has a maximum voltage of about $400 \mathrm{~V}$. The battery weights $174 \mathrm{~kg}$ and is tempered with a coolant water-glycol mixture. The battery is recharged after driving using a standard domestic power socket or a Wallbox [3]. In order to enhance the suitability of this urban vehicle for longer distances, a high temperature polymer electrolyte membrane fuel cell is integrated as a REX unit. The used fuel cell produces a maximum electrical power of about 6 $\mathrm{kW}$ and is supplied with hydrogen by a tank whose hydrogen capacity is about $0.9 \mathrm{~kg}$. The working temperature of the HT-PEFC is between $100-180{ }^{\circ} \mathrm{C}$. Triethylene glycol (TEG) is used as a coolant for the HT fuel cell. 
The energy consumption of the thermal management system shown in Fig. 1 serves as benchmark for the evaluation of new thermal management concepts in the HT-PEFC fuel cell electric vehicle. As can be seen from Fig. 1, this reference system contains two coolant circuits for the fuel cell and cabin (red circuit) and for the battery, power electronics and electric Motor (blue circuit). Electrical heaters are used for the battery, fuel cell and cabin air heating if the fuel cell is deactivated. When it is activated, the fuel cell waste heat is used for the cabin heating. In addition, the thermal management system contains an air conditioning system with an electrical compressor and a chiller for the battery cooling (green circuit).

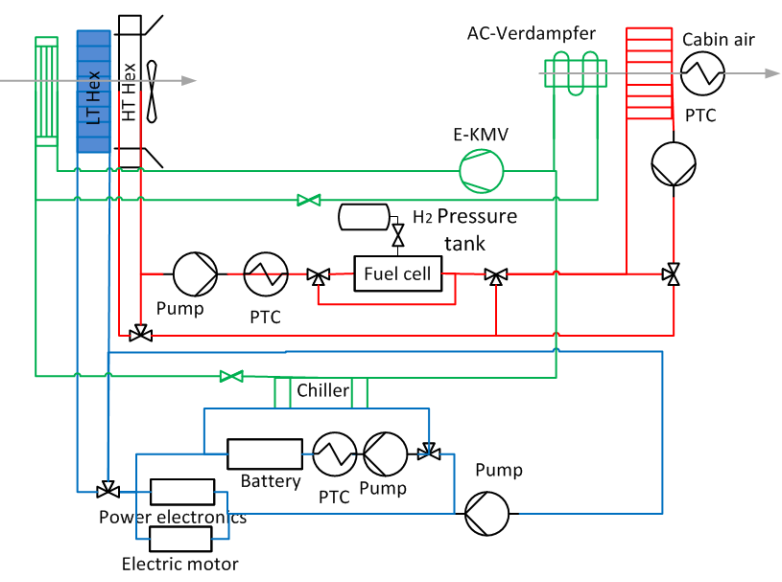

Fig. 1: Thermal management system for the HT-PEFC fuel cell vehicle

The data of the HT-PEFC-REX vehicle are summarized in the Table 1 and used for the parametrization of the vehicle simulation model.

TABLE 1: THE VEHICLE DATA OF THE HT-PEFC-REX VEHICLE

\begin{tabular}{||c|c||}
\hline $\begin{array}{c}\text { Maximum vehicle } \\
\text { weight }\end{array}$ & $1150 \mathrm{~kg}$ \\
\hline Motor type & $\begin{array}{c}\text { Magneto-electric } \\
\text { motor }\end{array}$ \\
\hline Continuous output & $35 \mathrm{~kW}$ \\
\hline Max. power & $55 \mathrm{~kW}$ \\
\hline Max. torque & $130 \mathrm{Nm}$ \\
\hline Battery type & Lithium-ion battery \\
\hline Battery capacity & $17.6 \mathrm{kWh}$ \\
\hline Battery weight & $174 \mathrm{~kg}$ \\
\hline Fuel cell type & $\begin{array}{c}\text { High temperature } \\
\text { polymer electrolyte } \\
\text { membrane fuel cell }\end{array}$ \\
\hline $\begin{array}{c}\text { Maximum electrical } \\
\text { power of the fuel cell }\end{array}$ & $6 \mathrm{~kW}$ \\
\hline $\begin{array}{c}\text { Maximum current of the } \\
\text { fuel cell }\end{array}$ & $130 \mathrm{~A}$ \\
\hline Fuel cell total mass & $68 \mathrm{~kg}$ \\
\hline $\mathrm{H}_{2}$ tank storage capacity & $0.9 \mathrm{~kg}$ \\
\hline Vehicle range at $-20^{\circ} \mathrm{C}$ & $152 \mathrm{~km}$ \\
\hline \hline
\end{tabular}

\section{B. Vehicle Simulation Model}

The overall vehicle simulation model has a modular structure and is made up of submodules of the drive train, fluid circuits and cabin, as shown in Fig. 2. The control module includes operating strategies for energy and thermal management.

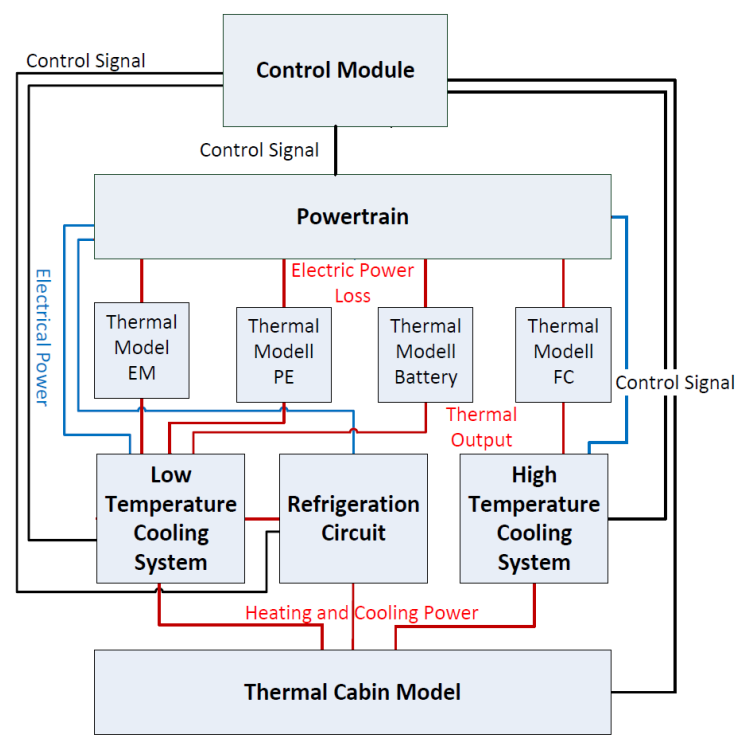

Fig. 2: Layout of the overall simulation model

For the modelling of the drive train, the AlternativVehicles library [4] is used. Fig. 3 shows the drive train model of the HT-PEFC fuel cell vehicle which consists of the chassis model for the longitudinal dynamics, the electric motor (EM) model, the model for the power electronics (PE), the simulation models for battery and fuel cell, whereas the last two components are generating electrical power for the drive train depending on the vehicle operating strategy.

As shown in Fig. 3, a DC-DC converter is implemented between the fuel cell and the battery, since both components have different voltage levels.

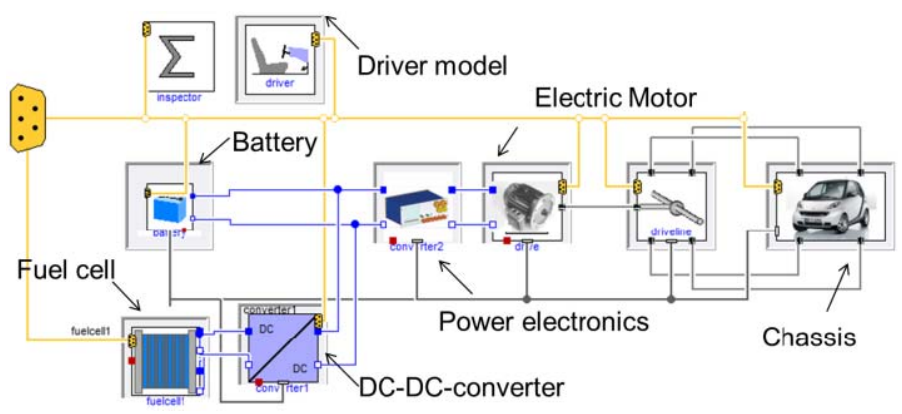

Fig. 3: Powertrain of the HT-PEFC-REX vehicle 


\section{THERMOCHEMICAL WASTE HEAT RECOVERY SYSTEMS}

\section{A. Waste Heat Energy and Heat Demand}

Before designing waste heat recovery concepts, one must first determine the magnitude of the waste heat energy to judge if it is significant to be stored, especially at low ambient temperatures.

Fig. 4 shows the heat loss during normal operation at $20{ }^{\circ} \mathrm{C}$ ambient temperature and the energy demand of the battery, cabin as well as the HT-PEFC during the cold start operation. The speed profile NEDC (New European Driving Cycle) [5] as a standard driving cycle is repeated in the vehicle simulation several times in sequence until the battery state of charge (SOC) is depleted to less than $5 \%$ and the hydrogen pressure tank is empty. In this case, the electrical range of the HT-PEFC-REX vehicle amounts to around $151 \mathrm{~km}$. The fuel cell is used as a range extender and delivers $5 \mathrm{~kW}$ to charge the battery or to drive the vehicle if the SOC is lower than $60 \%$.

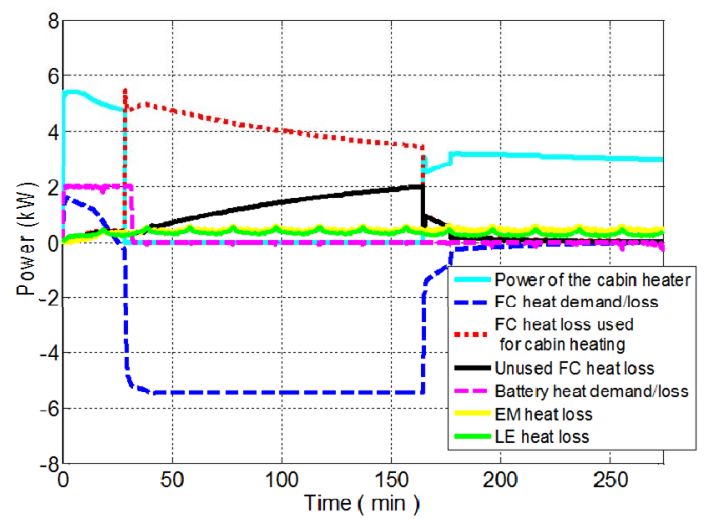

Fig. 4: Heat demand and heat loss of the HT-PEFC-REX vehicle during cold start and normal operation

The heat loss of the fuel cell is slightly higher than the electric power because of an averaged efficiency factor of about $48 \%$. As summarized in Table 2, the total unused waste heat energy of the fuel cell vehicle is equal to 6.3 $\mathrm{kWh}$ and is higher than the total electrical power consumption of the different heaters at start-up (4.8 kWh), thus a large opportunity exists to utilize this waste heat for heating purpose during the cold start operation.

\section{B. Thermochemical Heat Storage}

Thermochemical heat storages utilize the fact that reversible chemical reactions proceed under supply or release of thermal energy. Because hydrogen is already available in a fuel cell electric vehicle, metal powders known as metal hydrides $(\mathrm{MeH})$ which absorb and release hydrogen are used as thermal heat storage. The hydrogen absorption generates heat, since the reaction is exothermic. The reaction is reversible and endothermic (heat recovery), when hydrogen is released.
TABLE 2: WASTE HEAT OF THE HT-PEFC VEHICLE AND HEAT DEMAND

\begin{tabular}{||l|l|}
\hline $\begin{array}{l}\text { Fuel cell waste heat energy (REX } \\
\text { operation) }\end{array}$ & $12.3 \mathrm{kWh}$ \\
\hline \hline Cabin heat demand (REX operation) & $9.3 \mathrm{kWh}$ \\
\hline \hline $\begin{array}{l}\text { Unused fuel cell waste heat energy } \\
\text { (REX operation) }\end{array}$ & $3 \mathrm{kWh}$ \\
\hline \hline $\begin{array}{l}\text { Unused waste heat energy of the EM } \\
\text { und PE }\end{array}$ & $3.3 \mathrm{kWh}$ \\
\hline \hline $\begin{array}{l}\text { Unused waste heat energy of the } \\
\text { HT-PEFC-REX vehicle }\end{array}$ & $\mathbf{6 . 3} \mathbf{~ k W h}$ \\
\hline $\begin{array}{l}\text { Energy of the fuel cell heater } \\
\text { (cold start) }\end{array}$ & $1.3 \mathrm{kWh}$ \\
\hline $\begin{array}{l}\text { Energy of the battery heater } \\
\text { (cold start) }\end{array}$ & $1.4 \mathrm{kWh}$ \\
\hline $\begin{array}{l}\text { Energy of the cabin heater } \\
\text { (cold start) }\end{array}$ & $2.1 \mathrm{kWh}$ \\
\hline Total heat demand (cold start) & $\mathbf{4 . 8} \mathbf{~ k W h}$ \\
\hline
\end{tabular}

The chemical equation is:

$$
\text { Metal }+\mathrm{H}_{2} \leftrightarrow \text { Metalhydride }+ \text { Heat }
$$

To realize a long-term heat storage, the desorption step is separated in time and space from the adsorption step in such a way the desorbed metal hydrides material remains "charged" until the absorption process is started.

Depending on the material and the system design the theoretical energy density of such heat storage varies from $200 \mathrm{kWh} / \mathrm{m}^{3}$ to $500 \mathrm{kWh} / \mathrm{m}^{3}$ and is significantly higher than the energy density that can be achieved with sensible or latent heat storage [6].

With the simulation software Dymola, a general zerodimensional model for the thermochemical heat storage is created. This takes into account only one zone and no gradient in radial and longitudinal direction. It is based on the energy balance in the bed and cooling medium which are described by equations (2) and (3), respectively:

$$
\begin{gathered}
m_{M e H} \cdot c_{p, M e H} \cdot \frac{\partial T}{\partial t}=-k A \cdot \Delta T_{(M e H-H T F), \ln }-m_{H 2} \cdot \Delta_{R} H(2) \\
m_{H T F} \cdot c_{p, H T F} \cdot \frac{\partial T_{H T F}}{\partial t}=-m_{H T F} \cdot c_{p, H T F} \cdot \\
\left(T_{H T F, \text { out }}-T_{H T F, \text { in }}\right)+k A \cdot \Delta T_{(M e H-H T F), \ln }
\end{gathered}
$$

where $m_{\mathrm{MeH}}$ denotes the mass of the metal hydride, $m_{H T F}$ the mass of heat transfer fluid, $m_{H 2}$ the hydrogen mass, $c_{p, \mathrm{MeH}}$ the specific heat capacity of the metal hydride, $c_{p, H T F}$ the specific heat capacity of the heat transfer fluid, $\Delta_{R} H$ the specific enthalpy of the reaction, $\Delta T_{(M e H-H T F), l}$ the logarithmic temperature difference, $T_{H T F}$ the coolant 
temperature, and $k A$ the heat transition coefficient between metal hydride and coolant.

Eq. (4) and Eq. (5) describe the reaction kinetics of the absorption and desorption processes:

$$
\begin{gathered}
\dot{m}_{H 2}=\left(m_{H 2, \max }-m_{H 2}\right) \cdot k_{a} \cdot e^{\left(\frac{-E}{R \cdot T_{M e H}}\right)} . \\
\frac{T_{M e H G G}-T_{M e H}}{T_{M e H G G}} \\
\dot{m}_{H 2}=m_{H 2} \cdot k_{a} \cdot e^{\left(\frac{-E}{R \cdot T_{M e H}}\right)} \cdot \frac{T_{M e H G G}-T_{M e H}}{T_{M e H G G}}
\end{gathered}
$$

with the hydrogen flow rate $m_{H_{2}}$, the kinetics constant $k_{a}$, the metal hydride temperature $T_{\mathrm{MeH}}$, the metal hydride equilibrium temperature $T_{M e H_{G G}}$, the universal gas constant $R$ and the activation energy $E$.

The simple 1D simulation model is suitable for a complete vehicle simulation, data processing and controller design.

\section{Waste Heat Recovery Concept with one \\ Thermochemical Storage Tank}

In general, the thermal management system of a fuel cell electric vehicle must not only remove the unused waste heat during normal operation but also provide or produce the needed thermal energy for the start-up. As a thermochemical storage tank generates cooling during the hydrogen desorption and provides heating during the hydrogen absorption, metal hydride tanks can be used in the thermal management system of an electric vehicle to replace the electric components which consume electric power drawn from the battery.

The first concept proposed in this work consists of one $\mathrm{MeH}$ storage tank which is used to store the waste heat of the fuel cell and re-use it if needed. As shown in Fig. 5, the $\mathrm{MeH}$ is integrated into the fuel cell coolant circuit, which can transfer the heat to the cabin air via a built-in liquid-toair heat exchanger. The $\mathrm{MeH}$ storage tank is designed to store $43 \%$ of the unused fuel cell waste heat listed in Table 2 and is integrated into the high temperature (HT) coolant circuit in such a way that both the unsteady fuel cell and cabin heating could be supported by the $\mathrm{MeH}$ storage tank. Because of the high temperature level for operating the fuel cell, a suitable storage material $\mathrm{LaNi}_{4.75} \mathrm{Al}_{0.25}$ with a desorption pressure of 29 bars at around $160{ }^{\circ} \mathrm{C}$ is selected. Its mass is equal to $30 \mathrm{~kg}$.

The preheating of the battery is not changed and is provided by an electrical heater, as shown in Fig. 5 .

\section{Waste Heat Recovery Concept with two Thermochemical Storage Tanks}

The second concept consists of two metal hydride storages which are used for cooling and heating of the powertrain components and the passenger compartment. As shown in Fig. 6, one heat storage tank $(\mathrm{MeH} 1)$ is integrated into the fuel cell coolant circuit and the other $(\mathrm{MeH} 2)$ is integrated in the battery cooling circuit. $\mathrm{MeH} 1$ is designed to store the unused fuel cell waste heat at $160{ }^{\circ} \mathrm{C}$. MeH2 has the task to store a part of the EM and PE waste heat energy at $5{ }^{\circ} \mathrm{C}$ which is needed for the battery preheating.

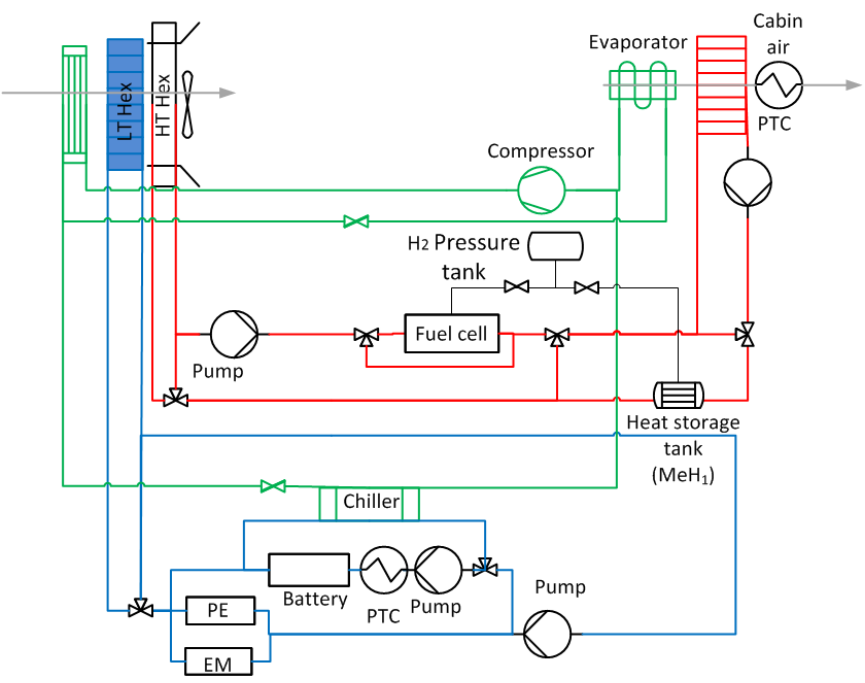

Fig. 5: Fuel cell waste heat recovery concept (concept No.1)

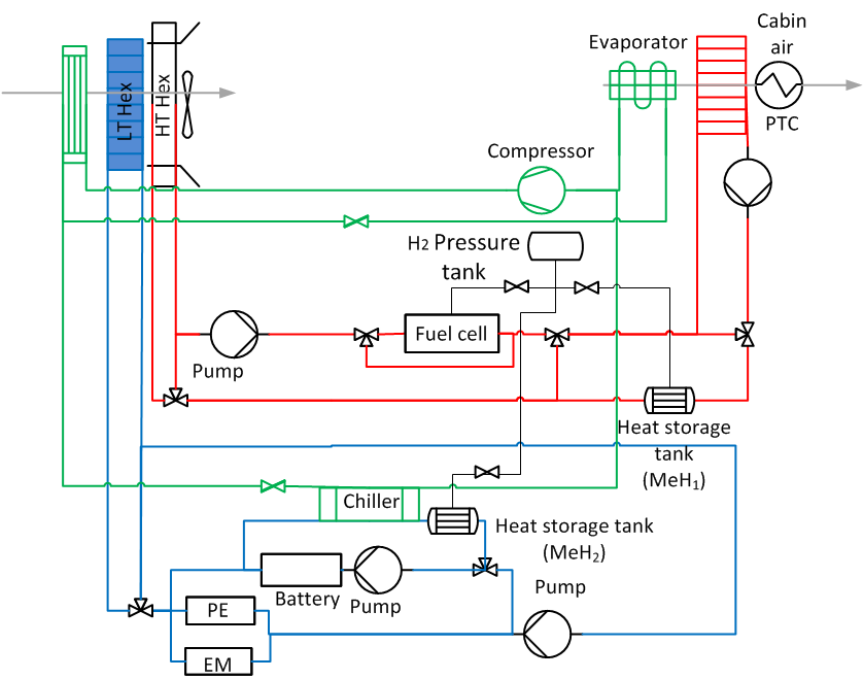

Fig. 6: Fuel cell waste heat recovery concept (concept No.2)

The MeH1 is filled with $\mathrm{LaNi}_{4.75} \mathrm{Al}_{0.25}$ and weighs $30 \mathrm{~kg}$, as in the first concept. To allow a cooling of the battery in the cooling case, a low temperature (LT) storage material $\mathrm{LmNi}_{4.91} \mathrm{Sn}_{0.15}$ is selected with a mass of $38 \mathrm{~kg}$. 
The thermochemical reactors are operated independently and are connected via a hydrogen pipe to a hydrogen pressure tank. The choice of different metal hydride materials is very important in order to allow the coupling between both reactors and to generate heat and cold in different places without the use of the hydrogen pressure tank and the fuel cell as hydrogen sink when the fuel cell is deactivated.

\section{RESUlts AND DisCUSSION}

As shown in Fig. 7, the energy released by the exothermic reaction in $\mathrm{MeH} 1$ is absorbed by the coolant and transferred to the fuel cell within the first 20 minutes. After the tank is fully charged and the heat production is stopped, the fuel cell is activated and the waste heat recovery process is started. One part of the fuel cell waste heat is used for the cabin heating and the other is stored by the heat tank, which releases part of the hydrogen to the fuel cell. Due to the re-use of the fuel cell waste heat for the cabin preheating, the electric range is increased by up to $14 \%$ compared to the HT-PEFC range extender vehicle.

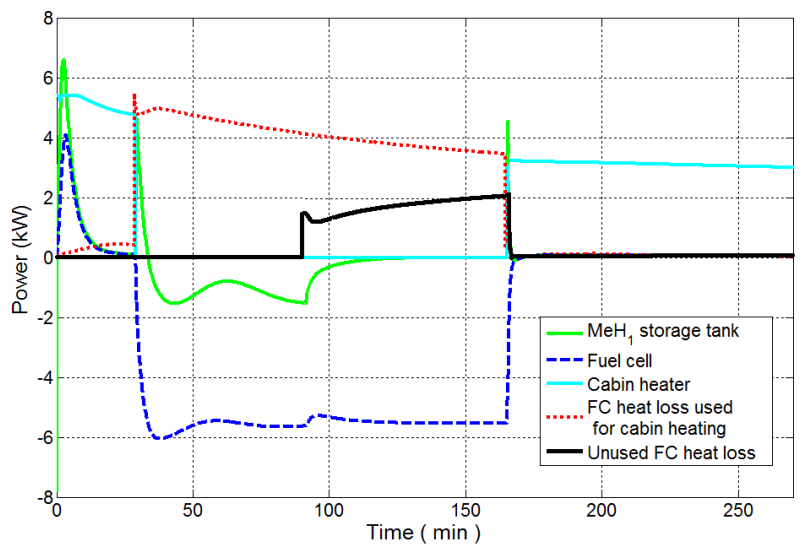

Fig. 7: The energy demand and heat loss of the fuel cell, metal hydride tank and cabin

The waste heat recovery in the HT coolant circuit of the concept No. 2 works similar to concept No. 1. However, in the low temperature coolant circuit a LT MeH is integrated. The pressure progression for the LT and HT metal hydride storage tanks is shown in Fig. 8.

Clearly, it can be acknowledged that a high hydrogen pressure is required during the heat generation process. Due to the pressure differences between the hydrogen pressure tank and the $\mathrm{MeH}$ storage tank, a pressure reducing valve should be placed between them. When the $\mathrm{MeH}$ is completely filled and excess heat is recognised, the hydrogen pressure is decreased in order to activate the endothermic reaction, whereby the waste heat of EM and $\mathrm{PE}$ is stored while the hydrogen is released.

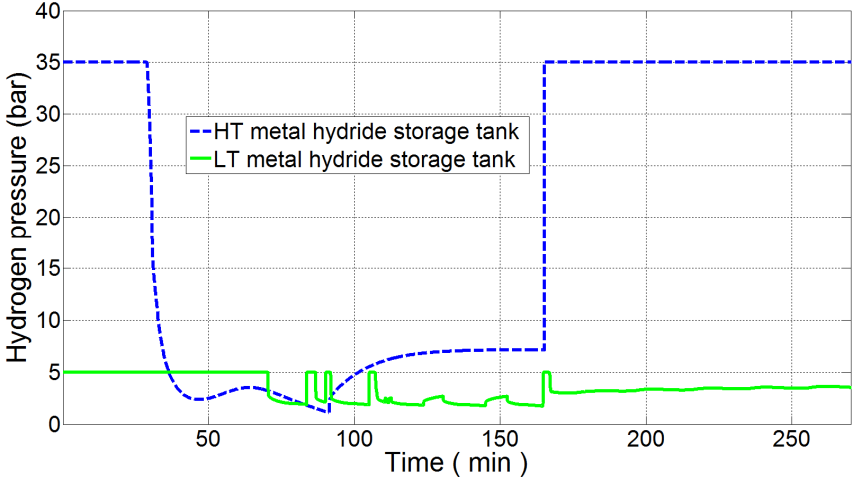

Fig. 8: Hydrogen pressure progression inside the LT and HT metal hydride storage tanks

As shown in the Fig. 9, the hydrogen released by the LT MeH presents a part of the hydrogen consumed by the REX unit. This part can be adjusted depending on the waste heat absorbed by the LT metal hydride and the design of its heat exchanger. The use of hydrogen pressure tank is necessary in order to compensate for any reduction in the amount of hydrogen released by the LT and HT metal hydride tanks and to deliver hydrogen at a constant flow to the fuel cell.

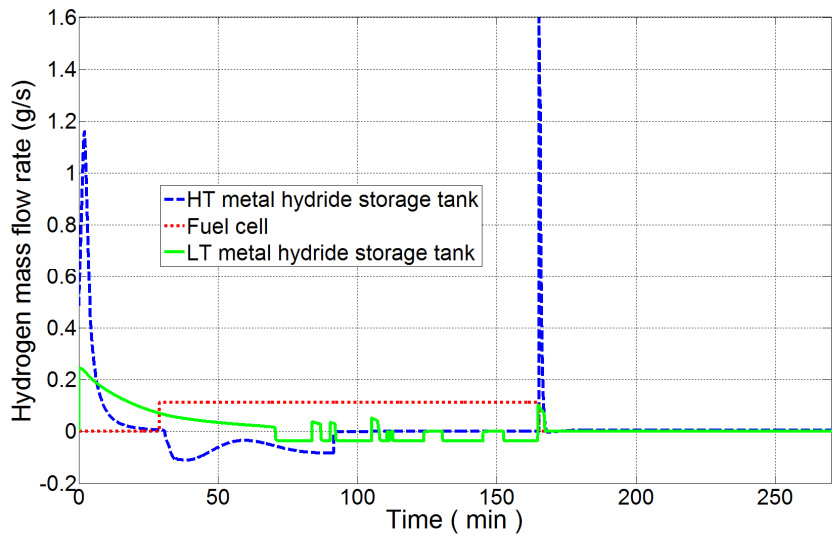

Fig. 9: Hydrogen mass flow rates of the metal hydride tanks and the fuel cell

Saving the electric energy needed for the cabin and the battery preheating by using the thermal energy of two different MeH tanks in concept No. 2 leads to an increase of the vehicle range of up to $17 \%$ compared to the reference system with electrical heaters. Although PTC heaters are smaller, lighter and cheaper than the proposed thermochemical energy storage system, they are not able to store the unused waste heat during normal operation and to use it for preheating instead of the electrical energy taken from the battery.

Unlike other waste heat recovery systems, such as mechanical and thermal heat pumps, the proposed thermochemical system is able to store thermal energy in order to offset short-term fluctuations in energy supply or 
demand. Other Solutions like combined heat and power (CHP) processes as well as thermoelectric generators don't use directly the waste heat [7]. In a first step, the waste heat is converted into useful energy (mechanical or electrical energy). In the second step, the useful energy in coupled into the energy system of the vehicle. Both conversion steps are not required in the proposed thermochemical system.

\section{CONCLUSION}

In order to increase the range of a fuel cell electric vehicle, thermal energy must be recovered from the powertrain waste heat. For the Fuel Cell Range Extender Vehicle (HT-PEFC-REX) developed by The DLR Institute of Vehicle Concepts [2], two waste heat recovery concepts using thermochemical heat storage tanks have been created. With these concepts, it is possible to store the waste heat of the powertrain components during normal operation and to release it for the start-up at very low ambient temperatures.

To evaluate the different waste heat recovery concepts in the entire vehicle, simulation models of these concepts including the thermochemical heat storage tanks are built in the simulation environment Modelica/Dymola and then integrated into an overall vehicle simulation model using the AlternativeVehicles library [4]. The NEDC (New European Driving Cycle) driving cycle [5] is used to determine the thermal system behaviour as well as the impact on the fuel cell vehicle range.
It has been found that the integration of thermochemical heat storages filled with metal hydride materials for the transient waste heat recovery leads to increase the range of the HT-PEFC-REX vehicle from $152 \mathrm{~km}$ up to $178 \mathrm{~km}$ at $-20{ }^{\circ} \mathrm{C}$ ambient temperature.

Future design will include issues of metal hydride tanks such as the use of metal hydrides with large hydrogen storage capacity and enhancing the heat transfer in the tanks. Next follows the design of functional models and their integration in the real vehicle.

\section{REFERENCES}

[1] L. Mardorf, P. Menger, M. Heiker, Automotive air conditioning with heat pump mode for electric vehicles-Comparison of the refrigerant 1234yf and R134a, Hochschule Osnabrück, Osnabrück, Germany, 2011.

[2] D. Dickinson and M. Nasri, Range Extender Vehicle Concept Based on High Temperature Polymer Electrolyte Membrane Fuel Cell, EVER 14, Monaco, March 2014.

[3] Daimler AG, Environmental brochure smart fortwo electric drive, ebrochure, 2013.

[4] T. Braig, H. Dittus, J. Ungethüm and T. Engelhardt, Modelica library AlternativeVehicles for vehicle system simulation, in the Proc. of ASIM Conference, Suisse, September 2011.

[5] EU commission, The Official Journal of the European Union, UN/ECE-R 83, Brussels, 2012.

[6] German Energy Agency (dena), Increasing the flexibility and efficiency of cogeneration plants by combination with heat storage systems, brief study, Berlin, April 2012.

[7] H. E. Friedrich, P. Treffinger, and M. Wolf Eckhard, Management of secondary energy and energy conversion of waste heat streams, The documentation CO2- The challenge for our future, pp. 195-213, Munich, Germany, July 2007. 